\title{
Pragmatic Aspects of Definition in Technical Terms Dictionary
}

\author{
Fitri Amilia ${ }^{1,2}$, Kisyani Laksono ${ }^{1}$, Budinuryanta Yohanes $^{1}$ \\ ${ }^{1}$ Universitas Negeri Surabaya, Indonesia \\ ${ }^{2}$ Universitas Muhammadiyah Jember, Indonesia \\ fitriamilia@unmuhjember.ac.id
}

\begin{abstract}
The Dictionary of Technical Terms has not shown any significant development on its existence. This dictionary has never been revised since its first publication in 1985 by the National Institute of Language. The dictionary which was presented in KBBI Daring has not also shown any significant changes. The means of defining terms are found to be similar to those of the common dictionary. It is evidenced that there has been no formula yet to define in the dictionary of technical term. This study aims to describe the pragmatic aspects of definition which is the distinctive feature in defining lemma in the dictionary of technical term. Nine different technical term dictionaries published in 1985by PusatPembinaandanPengembanganBahasa were taken as the sources of data to find out about definian and definiandum.Data were gathered through documenting and synthesizing the pragmatic aspects of definian. Pragmasematic approach is the basis of the pragmatic aspects found in the dictionary of technical term. The data were then analyzed using content analysis of similarities and distributions of the definian. The results showed that the pragmatic aspects can be seen from the citation of pragmatic features related to the user's need while the use of semantic aspects still do exist. The blend of these two is called as pragmasemantic. The findings of this pragmasemantic are indicated by the existence of context setting features, participants, ends, norms, genre, and evidence contexts.This type of pragmasemantic conception consists of a single definian. The findings of this conception is expected to help developing the dictionary of technical terms into learners' dictionary in which it emphasizes the contextual features of a lemma to assist the learners in grasping the lemma more precisely.
\end{abstract}

Keywords:lemma;pragmasemantic; single definian;term

\section{Introduction}

It was a minor study concerning with the use of dictionary of technical terms as a learners' dictionary in Indonesia. Number of studies on the use of learners' dictionary have been done, studies and criticisms on the use of learners' dictionary(Cohen, 2014); (Amalia, 2014); (Zou, Xie, \& Wang, 2015); study on the comparison of Indonesian-English dictionary(Jones, 2007); study about online dictionary(Mass'e, Chicoisne, Gargouri, Harnad, Picard, \& Marcotte, 2008); dan (Strawn, 2012); study about proverbs(Baker, 2016); 
(Mirahayuni \&Garnida, 2017). These are evidenced that the study about the dictionary of technical term is still very minor.

The semantic and lexicographic study on the dictionary was found (Paducheva, Rakhilina, \& Filipenko, 1992)as well as a study about pragmatic (Baker, 2016). Yet, the study using the combination of pragmatic and semantic approach has not been done.Another important background of this studywas also due to the weakness found in the use of semantic and lexicographic approach within the learners' dictionary (Setia, 2005). In fact, a learners' dictionary should have defined a lemma based on the users' needs (Xue, 2017). Thus, this study will apply semantic and pragmatic views to uncover the characteristics of defining meanings in the dictionary of technical terms.

The study of definition is possible to be taken from numbers of different point of views. Lanur (2007) proposed that logic is also study about definition, while Sudibya (2011) stated that definition is seen as a boundary or limit of a concept within a thing (word and lemma) briefly and precisely yet complete. This sort of definition concept is then applied by semantic as well as lexicographic. This type of definition, however, does not give consideration on the contextual features of lemma; therefore it does not serve the users'needs of the dictionary.

The combination of semantic and pragmatic in this study is named as pragmasemantic. Semantic concerns with meanings based on the triangle concept (Sumarsono, 2004); (Pateda, 2010); whereas pragmatic concerns with meaning of speeches in regard to its contexts (Leech, 1993). A lemma in the dictionary of technical terms definitely has meaning in regard to the semantic triangle as well as context based on the area of study. Combining semantic and pragmatic is therefore becoming a breakthrough and alternative in providing the operational definition of lemma.

The theory of pragmasemantic was first introduced by Molinowski(Senft, 2007). He urges that roles of culture always influence the language meaning and usage. He also emphasized that the meaning of a word is bound to the contexts. He applied the parmasemantic approach only in speeches found in a society. Yet, definians within the dictionary of technical terms were also forms of the speeches in defining and modifyinglemma. Every single lemma in the dictionary; possesses a context in which become the basis of arranging the definian. In other words, it can be said that every lemma in the dictionary is bound to its context.In this study, each dictionary of technical terms has its own context within the area of study which becomes the basis of defining lemma especially those of homonymy. These types of lemma are found both in technical dictionaries and the common ones.

The use of pragmasemantic in the defining meaning of word and lemma in the dictionary of technical terms is a combination of two aspects; semantic and pragmatic. The semantic aspect is mirrored in the statement of natural features of definian. These features are traced through referential approach. Whereasthe pragmatic aspect is reflected through the statement of contextual features within the area of study. The term pragmasemantic tells that semantic and pragmatic are conjointly have a crucial role in defining lemma in the dictionary of technical terms. Whereas semantic becomes the basis of referential definition and pragmatic becomes the balance of defining lemma based on the needs of the users.Pragmasemantic as an approach in turn carries its characteristics in defining meaning. The combination of these two, semantic and pragmatic, in practice gives its characteristics in defining meanings found in the dictionary of technical terms. Applying this approach appears distinctive characteristics of defining meanings found in the dictionary of technical terms 
which differs it from the common ones. This article will reveal the pragmatic aspects of defining meaning in the dictionary of technical terms through the application of pragmasemantic approach.

The pragmatic aspects in the definition are the contextual features of lemma in the dictionary of technical term. These aspects emphases on the value and accurateness of a concept of a lemma found in the dictionary. Hence, the users are able to employ the definition of the lemma as the basis in its application. In addition, the semantic aspect provides general viewsof lemma as found in the common dictionary. The combination of these two, pragmatic and semantic, is known as pragmasemantic.

The pragmatic aspects in the definition of lemma in the dictionary of technical terms are seen in the roles of its contexts. In this study, the theory of context used is Hyme's theory (Jhonstone \& Marcellino, 2010)known as SPEAKING. SPEAKING is to the acronym of Setting, Partisipant, End, Act Sequence, Key, Instrumental, Norm, dan Genre. Settingrefers to the setting of utterances or speeches. Participants refer to those involved in the application of the speeches or utterances within a communication. Ends mean as the purpose of the communication. Act sequencerefers to the content and forms of the utterances or speeches. Instrumentalitiesdenote the language tracks employed in the communication. Genredesignate the types of forms in the communication. These eight contexts are found in the direct (oral) speeches in which can be used in researching texts.

The study of the pragmatic aspects here in turn confirms the distinctive ways of defining meanings in the dictionary of technical terms from the common ones. The distinction is due to the connectedness of a lemma to its contexts within the area of study in the dictionary of technical terms. Whereas in the common dictionary a lemma is defined in the basis of its concepts but not restricted in a certain area of study, or in other words a lemma is defined freely regardless to its contexts. The distinction of the conception reflects the role of pragmatic as the context of the area of study usedin the dictionary of technical terms. This role aims to explain the features of lemma in precise manner. It is in line with the results of the study done by Xue (2017) which revealed that a dictionary must include the concepts of lemma based onits users' needs as well as information concerning with the contexts of the lemma itself.

A dictionary is regarded as a reference book to find out the meaning of words. Setiawan (2009)urged that a dictionary refers to a reference guide consisted vocabulary, meanings, and its usages in one language or more. Based on the definition, a dictionary is used to comprehend words, meanings and examples of its usage. In this study, the dictionary of technical terms is regarded as a special or distinctive reference book which is tied or bound to the contexts within a particular area of study concerning with the word meanings and the examples of its usage.

Each technical dictionary has its own name and specific scope to cover. The vocabularies in the entry list are also arranged based on its usage on the area of study. The users of the dictionary are specifically mentioned in some dictionaries as in the learners' dictionary. The Dictionary of Information and Library Management for example it reveals that the dictionary contains vocabulary terms related to its title (Black, 2009). The dictionary also declares that the users are those related to occupations or professions related to the contexts of the dictionary. This confirms the statement that each type of dictionary must recognize who will be the users (Khumalo, 2009). 


\section{Methodology}

The study has nine different technical terms dictionaries published in 1985 by Pusat Pengembangan danPembinaanBahasa as the sources of data. The researcher visited regional library and Language Institutes to gather documents on technical dictionary. In addition, the researcher also did some interviews in the Language Institute about the development of local language dictionary. It was found out that there wasn't any data revealed the existence of any technical dictionaries in 1985. Furthermore, the researcher also asked to the staff of Glossary and Terms of the Language Institute which also revealed similar data that there weren't any files or printed documents about technical dictionary have ever been recorded. Instead, the deeds have come across nine different dictionaries. Those are The Dictionary of Shipping (Sogiono, Andrianto, Sukotjo, Wartono, \& Asianto, 1985), The dictionary of Fish Cultivation (Sumantadinata, Haris, Dana, Angka, \& Mokoginto, 1985), The Dictionary of Accounting (Tjitrosidojo, Subijanto, Prasetio, Koesnadi, \& Marnandus, 1985), The Dictionary of Zoologi (Sastrohadinoto, Sugirl, Somadikarta, Soesitiadi, \& Sastradipradja, 1985), The Dictionary Meteorology(Wirjohamidjojo, Susanto, Sudjono, Sujitno, \& Suhartono, 1985), The Dictionary Governance (Awanwinata, Manan, Magnar, Ermaya, \& M, 1985), The Dictionary of Mineral Technology(Soetjipto, Sumardi, Sulistijo, Sudarsono, \& Sugeng, 1985), The Dictionary of Politics(Muhaimin, Rais, Sugiono, Hallina, \& Salam, 1985), andThe Dictionary of Market Administrations(Ramli, Sian, Walandouw, Nurmantu, \& Kasim, 1985). Those are regarded as the sources of data of this study. The pragmatic aspects will be uncovered within the definian and definiandum.

The data on definian and definaiandum were read, marked, classified, carefully synthesized, discussed and finally categorized into number of groups. The activity of reading the data was done repeatedly. The marking activity was done by giving codes as APS for the findings about pragmasemantic aspects. APS code in marking activity for pragmasemantic aspects refers code $P$ as the findings on pragmatic aspects, whereas code $\mathrm{S}$ as the findings on semantic aspects. The activities were done carefully by researching the data of $A P S, P$ and $S$ to get the valid data. The follow up step was then having a discussion forum to discuss about the findings to meet the agreement. The valid data were classified into groups of categories and given codes. Whereas the invalid ones were put into the groups categorized as in-need of revision data code.

The aforementioned steps were the application of documentation technique and also triangulation of data. Through this technique, the researcher discovered the characteristics of definition in the dictionary of technical terms. This study was limited to the pragmatic aspects of definition as the main distinctive components of definition.

The findings data were analyzed using content analysis of similarities and distributions of the definian. Having the analysis, it revealed the types of contextual features of a lemma and the correctness of definition in the definian. Data reduction was done three times before doing the analysisfor the sake of effectiveness of the study. In the reduction phase, the data taken were only gathered from three different technical dictionaries as the representations of the other similar data from the rest of the dictionaries. The gathered data from the technical dictionaries were also compared to those of the common dictionary to meet the triangulation technique of gathering the data as the source of data in the study. 


\section{Result}

\subsection{Contexts in the Technical Dictionary}

The pragmatic aspect in the technical dictionary is seen in the contextual features. In this study, the theory of context is based on the theory of SPEAKING by Hymes. From the eight context features mentioned by Hymes, there were only five found in the study. The five contexts were shortened as SPENG which refers to setting, partisipant, end, norm, dan genre. Setting in this study refers to location, time and living system. Participants defined as subjects of persons or groups of persons, or other things. End labeled as the concept or the purpose of lemma. The term norm is seen as rules within lemma. Genre referred to the concepts of lemma. The following is the data of context setting

(1) Indonesia

nama negarayang diproklamasikan pada tanggal17 Agustus 1625 (APS, KTN)

Data (1) mentioned concept + nation's name as genus, the concept of setting is seen from the differensia that is +proklamasi, +17 Agustus. Concept of setting in data (1) is classified as the living system. This concept is appropriate with the area of study about Government. In the study of governmental system, a nation has a concept + to govern, + to conduct interactions among the citizens, to rule the society (Padamu, 2007). In other text, the term nation in the governmental study is related to the concepts of + origin of a nation, + disappearance of a nation, + elements of nation, + purpose of nation (Apriyadi, 2016). Those concepts indirectly related to the concept of + freedom or + proclamation. Thus, the concept of context in differensia refers as the pragmatism of definition. The concept of definition (1) found in this example is different from the one found in the common dictionary. The following is the definition of lemma Indonesia found in the common dictionary:

(1a) Indonesia

nama negarakepulauan diAsia Tenggara yang terletak di antara benua Asia

dan benua Australia (KBBI Daring, 2016)

Data (1a) also states the concept of setting, it mentions +Asia Tenggara (South East Asia), + Benua Asia (Asian Continent), and +Benua Australia (Australian Continent). Those setting concepts denote places or locations. Here, similar lemma is presented differently; it shows that the distinction of concept is the main concern. By doing so,it gives evidence that the role of pragmatic aspects is very crucial in defining lemma in the technical dictionary. Data (1) is the example of pragmatic aspect in defining lemma in technical dictionary.

In this study, the findings on context found context called as evidence context. The data below shows the context:

(2) agenda

(daftar) pekerjaan yang harus dilaksanakan; agenda seorang auditor terdiri dari berbagai catatan yang dibuatnya selama ia melakukan pemeriksaan di lapangan, berupa berbagai pertanyaan dan lain-lain, untuk diperhatikan (dibahas, dibicarakan) kemudian (APS, KA)

The definition of lemma (2) consists of + (list of) duties + has to be accomplished Semanticaly, this concept can be traced in two ways: referentially and contextually. In this 
discussion however, those two conceptions will not be further discussed. Yet, this will be focused more on the contextual concept within the evidence of lemma.

In the evidence of lemma, the usage of lemma is written within the context area of study where the lemma is found. Lemma (2) is found in the Dictionary of Accounting. Within the context of Accounting, lemma (2) is related to types of duties in this area of study. In this evidence, the users of the dictionary will understand the concept of the lemma within the area of study, not only to realize the definian. It shows that the role of context is very important in defining a lemma. This context is called as evidence context which is found only in the dictionary of technical terms.

The explanation on lemma (2) implies that a lemma is a term which is bound within the context of the area of study. Here is the evidence shown in the KBBI on the lemmaagenda related to its definition.

(2a) agenda

acara (yang akan dibicarakan dalam rapat): hal itu tercantum juga dalam

- rapat(KBBI Daring, 2016)

The marking (-) in the evidence definition (2a) indicates the use of the lemma. The evidence of lemma in (2a) realizes the concept written in the definian. The marking (-) is possible to be filled with a lemma or a definian. Those evidences are known as the evidence of conception. These evidence are different from those found in data (2) in which it not only realizes the definian of the lemma but also to explain the concept of the lemma usage which is bound to its area of study.

There are some forms on this evidence, but it will not be discussed further in this article. This article will only prove that evidence in the technical dictionary is not only as a part of a definian, but also as the context of a conception.

The above explanation evidence context in the definition shows the pragmatic aspect in defining lemma. The evidence is not only modifying a lemma but it also realizing the usage of lemma or term in regard to its area of study. Furthermore, evidence also relates its users more closely in understanding the concept of lemma in the technical dictionary. For these reasons, evidence context is proposed as the finding of the study of the concept of definition in the dictionary of technical term.

\subsection{The Forms of Definition in the Dictionary of Technical Terms}

Pragmasemantic which is the combination of semantic and pragmatic aspects used in definition conception is an ideal conception in defining some forms of definition. The pragmatic aspects limit a lemma with the contextual concept. This limitation is seen in the defining a single definian. The single definian shows unity in a conception. Through this definian, the semantic and pragmatic aspects of a lemma have been comprehensively written.

A single definian constitutes a unity of conception which is marked with the nonexistence of numbers in defining the concept of a lemma. In contrast, the numbering indicates complexity of concepts in defining a lemma; which means that a lemma can be defined as the first, second, or third definian and so on, depends on the complexity of meanings of a lemma.

For the technical dictionary, the concept of lemma is bound to its contexts within its area of study. This concept has been the basis of its conception which differs this type of conception of lemma from the one in the common dictionary. Thus, the corpus data in the technical dictionary must pay careful attention to its lemma and usages. 
In addition, technical dictionary and common ones must be diverse. The technical dictionary registers lemma or terms related to its context on the area of study. Whereas the common dictionary,lemma registers are in the forms of vocabulary, varieties of languages, and its development. For these reasons, the concept of definition of these two types of dictionary, technical and the common dictionary, are different. In the common dictionary, a lemma is defined loosely form its context, and its causes the multi-definiansposseses by a lemma. Each of the definians is given an example of its usage based on its meaning. However, this cannot be done for the definian of lemma in the technical deictionary.

Technical dictionary consists of lemma complete with its concepts within a particular context of the area of study. These concepts must be written in one single definian which reflects the unity of concepts of a lemma. The definian, implies the concept of lemma in a complete and meaningful understanding. Therefore providing more than one definians in the technical dictionary must not occur.

On the other hand, having more than one definians is applicable for the common dictionary. The results of observation showed that, a lot of lemma in the common dictionary were given more than one definians. Those definians are differed based on the contexts of its usages. For example in the lemmabesar means big. In the common dictionary this lemma has more than one definians. The following are the definians:

\section{(3) besar/big}

1) lebih dari ukuran sedang/ more than medium

2) tinggi dan gemuk/tall and fat

3) $a$ luas; tidak sempit/large; not narrow

4) $a$ lebar/ wide

5) a ki hebat; mulia; berkuasa/great; honor; powerful

6) a ki banyak; tidak sedikit (tentang jumlah)/many; not few (in numbers)

7) a ki menjadi dewasa/ to be mature

8) a ki lebih dewasa daripada sebelumnya/to be more mature than before

9) a ki penting (berguna) sekali/very important (KBBI Daring, 2016)

Nine definians are given in data (3). The first definian is given based on the context of the size on an object or something which has volume or mass, it can be seen from the sentence "Onde-ondeinibesar" it means that the "onde-onde" represent the object which its size or volume is more than medium which is more than its common size. The word "big" in this statement means there is a meal which has size more than the medium size or more than the common size of this meal. The second definian has the the context of a particular person whose body is tall and fat. It is seen in the statement "kamu besar ya", ("You are big"), which means the person is having a tall and big size of body. The following definiansthird, fourth up to seventh also state similarly. In the eighth definian, the context is a person who is growing, it means as a symbol. It is seen from the statement "wah, lama tidak bertemu, sekarang sudah besar" ("long time no see, now you are big). The word big in the statement means growing to be more mature and older. The variations of definians on the word "big"(besar) shows that each definian is bound to a particular context which is not similar to one another.

These forms of definians should have not been existed in the technical dictionary since the conception of a lemma has been based on a particular context in one area of study. This basis will be the fundamental consideration in the arrangement of definition comprehensively. 
In fact, however, the results of the observation revealed that there are some lemmas defined in number of definians. Some are using similar genus but different in differentia. Some are using different genus but similar in differentia. Some are using genus and differentia which are almost similar. In addition, some revealed no relationship or similarities among definians. These findings indicated that there has been no comprehensive way of lemma conception in the technical dictionary due to its vogue or unclear availability of the corpus data. Below are the findings aboutmulti-definians in technical dictionary.

\section{(4)Angkatan 45}

1) Dalam dunia sastra, nama ini menunjuk kepada para penyair dan pengarang yang mulai aktif menulis sekitar zaman pendidik Jepang (1942 - 1945);(P, KP)

2) Dalam dunia kenegaraan, nama ini menunjuk kepada para pejuang kemerdekaan Indonesia sekitar 1945 (Kamus Istilah Politik, 1985) (P, KP)

Two definians are given for data (4) with different concepts. The difference is due to the dissimilar context found in the lemma. The 1st definian has the context of literature period, while the $2^{\text {nd }}$ definian has the context of governance /politics. The $2^{\text {nd }}$ definian is considered to be précised; that is in the context of politics found in the Technical Dictionary of Politics. The $1^{\text {st }}$ definian is considered not contextually focused in defining a lemma in the technical dictionary. This type of definian should have never been existed in the technical dictionary for the existence of definian which does not regard to the context of lemma. Other forms of neglecting of the lemma contexts were also existed. Yet, they will not be discussed further in this article for they do not match with the criteria of data required in the study.

The unstructured conception in the technical dictionary is indicated with the absence of context in defining lemma. It denotes the un-readiness of the components of meanings of lemma and also the components of pragmatic. Consequently, two or more definians are found in defining one lemma. It gets even worse when in one technical dictionary provides multiple meanings, as if it offers similar meanings as found in the common dictionary. The whole definians are not bound to any contexts, so that there is no exact concept for a lemma in a particular area of study.

The unclearly corpus means un-readiness of data in the technical dictionary. This is visible from the non-existence of the differences in conceptions between technical dictionary and the common one. Lemma in the common dictionary is the vocabulary in the language of the dictionary. Whereasin technical dictionary, a lemma means a term which its meaning is bound to its context in the particular area of study. As a result, it will be awkward if the conception in the technical dictionary has precisely similar conception to that of the common dictionary.the example below shows the pragmatic aspect found in the technical dictionary.

(5) adaptasi

suatu perubahan dalam struktur atau fungsi organisme sehingga dapat mengatasi secara lebih baik suatu keadaan dalam lingkungan perairan tempat hidupnya (APS, KBDI)

The concept of + changes (perubahan) belongs to semantic aspect, but the concepts of + structure (struktur), + function (fungsi), + organism (organism) , + water (perairan) will only be possible when viewed pragmatically. Those concepts belong to pragmatic aspects of lemma based on the area of study. These pragmatic aspects denote the characteristics of defining lemma in the technical dictionary. 
The aforementioned statements about defining lemma reveal that the characteristics of defining lemma in the technical dictionary can be seen from its combination of semantic and pragmatic in its conception. The pragmatic aspect is drawn in its conception of a lemma as a single definian in which it is arranged in such a way by regarding to its semantic aspect and context or pragmatic aspect of the lemma. In other words, technical dictionary has a distinctive characteristic which can only be found in this type of dictionary. The characteristic is that it only provides one single definian for each lemma registered. This single definian of lemma constitutes the unity of concept in regard to its semantic and pragmatic aspects.

\section{Discussion}

Two features of pragmatic aspects of definition in the technical dictionary comprise the concepts which relay on the context theory and the forms of the definition given are based on the context itself. The findings have become the basis in developing technical dictionary in Indonesia. This would have been very valuable since the technical dictionary published in 1985 has never been revised. There of course will have been the development of technical dictionary and lemma in line with the needs in learning.

Constructing a technical dictionary should regard to the learners' needs. The needs of the exact and precise definition based on the context of a particular area of study. This statement is in line with what has been stated by Khumalo that every dictionary must regard to its learners (Khumalo, 2009). Another strong proposition is also urged by Wellman as he asserts that learners' dictionaries should be simple, clear, understandable and applicable (Herbst, Lorenz, Mittmann, \& Schell, 2006).

The results of the study revealed that the pragmatic aspects of defining lemma in technical dictionary are in the forms of context features. The contexts found were written in the acronym of SPENG which was derived from SPEAKING proposed by Hymes. The contexts of AKI cover act sequence, key, and instruments. Act sequence refers to one similar thing, which means a conception. The content and forms of this context has been discussed on the definition patterns or forms, not as a context. Key feature represents manner and tone. Within the context of dictionary, these two things are not covered. Tones within the texts in the dictionary are marked with some punctuations;koma (,), colon (;), and semicolon (:). A koma(,)marked the parts which are decsribes or illustrated.A colon (;) is used to separate the forms which are almost alike or similar in meaning (synonymy), and as a mark for the end description of a sub-lemma, and polisemi. A semi colon (:) is used to describe a lemma from its example in the sentence. Those three punctuations are common in the dictionary. Therefore, the key feature is not discussed further in this study. The feature instruments refer to the language of the dictionary. This feature has its basis rule by using the written standard Bahasa Indonesia, and based on the lexicographic norms in Indonesia. The non-existence of AKI is tolerable as the form of adjustment to the sources of data needed in this study. Therefore, the contexts of AKI will not be found in the text of definition in the dictionary; instead, they become rules of definition in lexicography.

The contexts found in this study are called as evidence context. Evidence consists of modifying concept in the forms of examples on usage of the lemma. This evidence can be found in the forms of synonymy or antonyms of lemma, other lemma, the operational and procedural use of the lemma. These evidence contexts have never been uncovered within the 
area of context. Evidence is called as context for it is able to assist learners and users of the dictionary to comprehend the meaning or definition of a lemma. The results of the study revealed that there is a specific distinction between technical dictionariesfrom the common one. This specific distinction refers to the existence of evidence. Using evidence, the concept of a lemma can be explained or defined in detailed to see the distinction between the conception of terms and common words

Those contexts are aimed to call for semantic and pragmatic features of a lemma. A lexicographer will construct the semantic and pragmatic concepts of a lemma in the complete definian as one unity. The unity of the definian is seen in the single definian given for eachlemma, not in two or more. The unity of definianmust be of the serious attention of the lexicographer as what has been stated by Wellman that learners' dictionaries should be simple, clear, understandable and applicable (Smit, 2006). A single definian has fulfilled those four criteria proposed by Wellman as the characteristics of a dictionary.

Definition with two or more definians shows the incompleteness in defining a lemma in pragmasemantic way. This incompleteness implies that a definian is not completely defined and united. This incompleteness was due to the separation of the lemma concepts. In the definition using single definian, a definian is arranged in regard to the semantic and pragmatic concepts based on the users'need. This single definian will reflect the features of contexts as the pragmatic aspects of a definition.

Within the activity of lexicography, ways and forms of making a definition can be applied using semantic, pragmatic, and pragmasemantic approaches. The approaches selected will reflect the concepts and features of a lemma. The semantic aspects are commonly found in the common dictionary. In contrary, the pragmatic aspects must exist in the explanation or definition of a lemma which is bound to a particular area of study. A combination of semantic and pragmatic aspects in the conception of a lemma in a laerners' dictionary is the realization of ways and forms if an ideal definition. Thus, the existence of pragmatic aspects will not be neglected in the conception of a learner's dictionary.

\section{Conclusion}

Definition in technical dictionary means as a revealing the concepts of lemma as a term which is semantically and pragmatically meaningful. Semantic meaning implies a notion of relationship between a lemma as a common word and a lemma as a term. The pragmatic meaning of a lemma denotes a distinctive concept of a lemma as a common word and a lemma as an exceptional word.

The pragmatic aspect of definition in a technical dictionary is reflected in the existence of SPENG contexts and the evidence as the contextual features. The existence of context can be found in the single definianof definition. This single definian reflects a united conception based on the needs of users as well as the type of dictionary.

\section{Acknowledgements}

The author thanks the Directorate of Higher Education of the Republic of Indonesia for providing a dissertation grant for this study. The author also thanks the head of departement of Language and Literature Education Postgraduate Program of Universitas Negeri Surabaya, the head of LPPM Universitas Muhammadiyah Jember, the dean of Faculty 
of Teacher Training and Education, and the head of departement of Indonesian Language and Literature Education.

\section{References}

Amalia, D. (2014). "Bottom-up" Approach in Making Verb Entries in a Monolingual Indonesian Learner's Dictionary. Lexicography, pp. 73-94.

Apryadi, M. (2016, Desember 25). https://muhammadapryadi.wordpress.com. Dipetik Maret 26, 2018, dari https://muhammadapryadi.wordpress.com: https://muhammadapryadi.wordpress.com/2016/12/25/ilmu-negara-dan-ilmu-tatanegara/

Awanwinata, R., Manan, B., Magnar, K., Ermaya, P., \& M, R. S. (1985). Kamus Istilah Tata Negara. Jakarta: Pusat Pengembangan dan Pembinaan Bahasa.

Baker, W. (2016). Shakespeare's insults: a pragmatic dictionary. Choice, pp. 1593-1594.

Black, A. (2009). Dictionary of Information and Library Management. London: Bloomsbury Publishing.

Cohen, J. (2014). Biographical Dictionary. Reference Reviews , pp. 47-48.

Jhonstone, B., \& Marcellino, W. (2010). Dell Hymes and The Etnopragmatic of Communication. Dalam R. Wodak, B. Johnstone, \& P. E. Kerswill, The Sage Handbook of Sosiolinguistic (hal. 1-17). London: Sage Publishing.

Jones, R. (2007). A Comprehensive Indonesian-English Dictionary. Journal of the Royal Asiatic Society, pp. 93-95.

Herbst, T., Lorenz, G., Mittmann, B., \& Schell, M. (2006). Lexikografie, ihre basis- und nachbarwissenschaften. (englische) wörterbücher zwischen 'common sense' und angewandter theorie. Lexikos, (16) 318-326.

Kementerian Pendidikan dan Kebudayaan. (2016, Januari). KBBI Daring. Dipetik September 18, 2017, dari kbbi.kemendikbud.go.id: https://kbbi.kemdikbud.go.id/entri/perempuan

Khumalo, L. (2009). Looking beyond Meaning in the Advanced Ndebele Dictionary. Lexikos , pp. 102-111.

Leech, G. (1993). Prinsip-Prinsip Pragmatik. Jakarta: Universitas Indonesia.

Mass'e, B. A., Chicoisne, G., Gargouri, Y., Harnad, S., Picard, O., \& Marcotte, O. (2008). How Is Meaning Grounded in Dictionary Definitions? Online. Coling 2008: Proceedings of 3rd Textgraphs workshop on Graph-Based Algorithms in Natural Language Processing (pp. 17-24). Manchester: http://www.aclweb.org/anthology/W08-2003.pdf.

Mirahayuni, N. K., \& Garnida, S. C. (2017). 'Sapi Perah' or 'Kuda Beban': Cultural Values in Indonesian Proverbs Associated with Horse, Cow, Buffalo, and Donkey. The 4th International Conference on Language, Society and Culture in Asian Contexts (LSCAC) (pp. 175-186). Surabaya: Knowledge E.

Muhaimin, J., Rais, A., Sugiono, Hallina, I., \& Salam, U. (1985). Kamus Istilah Politik. Jakarta: Pusat Pengembangan dan Pembinaan Bahasa.

Padamu, A. (2017, Juli 10). https://www.padamu.net/. Dipetik Maret 26, 2018, dari https://www.padamu.net/: https://www.padamu.net/pengertian-negara-dalam-ilmupolitik 
Paducheva, E. V., Rakhilina, E. V., \& Filipenko, M. V. (1992). Semantic Dictionary Viewed As A Lexical Database. Actes The Coling-92: Proc. of Coling -92 (pp. 1295-1299). Nantes: Actes The Coling.

Pateda, M. (2010). Semantik Leksikal. Jakarta: Rineka Cipta.

Ramli, R., Sian, T. T., Walandouw, H., Nurmantu, S., \& Kasim, A. (1985). Kamus Istilah Administrasi Niaga. Jakarta: Pusat Pengembangan dan Pembinaan Bahasa.

Sastrohadinoto, S., Sugirl, N., Somadikarta, S., Soesitiadi, H. D., \& Sastradipradja, D. (1985). Kamus Istilah Zoologi. Jakarta: Pusat Pengembangan dan Pembinaan Bahasa.

Senft, G. (2007). Bronislaw Molinowkski and Linguistic Pragmatics. Lodz Papers in Pragmatics, pp. 79-96.

Setiawan, T. (2009). Analisis Struktur Kamus Monolingual Bahasa Indonesia. LITERA, pp. $179-192$.

Soetjipto, R. B., Sumardi, D., Sulistijo, Sudarsono, A., \& Sugeng, B. (1985). KamusIstilah Teknologi Mineral. Jakarta: Pusat Pengembangan dan Pembinaan Bahasa.

Sogiono, Andrianto, P., Sukotjo, Wartono, M., \& Asianto. (1985). Kamus Istilah Perkapalan. Jakarta: Puat Pembinaan dan Pengembangan Bahasa.

Strawn, N. (2012). Optimization over finite frame varieties and structured dictionary design. Applied and Computational Harmonic Analysis , pp. 413-434.

Sudibya, D. W. (2011). Logika. Jakarta: Indeks.

Sumantadinata, K., Haris, E., Dana, D., Angka, S. L., \& Mokoginto, I. S. (1985). Kamus Istilah Budi Daya Ikan. Jakarta: Pusat Pembinaan dan Pengembangan Bahasa.

Sumarsono. (2004). Buku Ajar Filsafat Bahasa. Jakarta: Gramedia.

Tjitrosidojo, S., Subijanto, S. D., Prasetio, J. A., Koesnadi, R., \& Marnandus, T. E. (1985). Kamus Istilah Akuntansi. Jakarta: Pusat Pembinaan dan Pengembangan Bahasa.

Wirjohamidjojo, S., Susanto, R., Sudjono, Sujitno, \& Suhartono. (1985). Kamus Istilah Meteorologi. Jakarta: Pusat Pengembangan dan Pembinaan Bahasa.

Wójtowicz, B. (2017). Revisiting Lemma Lists in Swahili Dictionaries. Lexikos; Stellenbosch , pp. 561-577.

Xue, M. (2017). Representing the Cultural Dimension of Meaning in Learner's Dictionaries From the Perspective of Chinese EFL Learners in L2 Reception. Lexikos , pp. 578596.

Zou, D., Xie, H., \& Wang, F. L. (2015). The Use of Monolingual Mobile Dictionaries in The Context of Reading by Intermediate Cantonese EFL Learners in Hongkong. Critical CALL - Eurocall Conference (pp. 569-574). Padova: Research Publishing.net. 